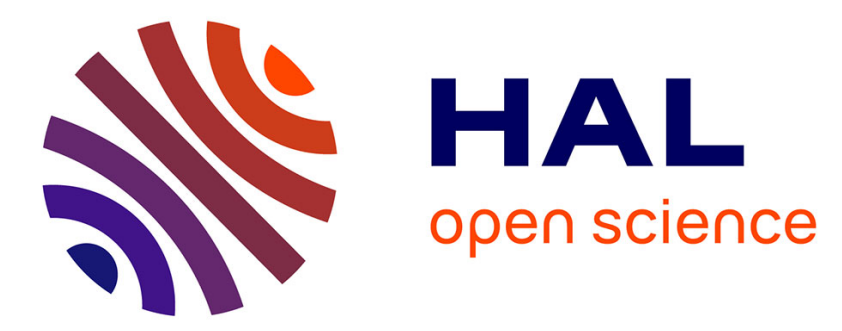

\title{
Regulation of growth: Epigenetic mechanisms?
}

Laurent Kappeler, Maud Clemessy, Sarah Saget, Lyvianne Decourtye, Yves Le

Bouc

\section{To cite this version:}

Laurent Kappeler, Maud Clemessy, Sarah Saget, Lyvianne Decourtye, Yves Le Bouc. Regulation of growth: Epigenetic mechanisms?. Annales d'Endocrinologie, 2017, 78 (2), pp.92 - 95. 10.1016/j.ando.2017.04.004 . hal-01533314

\section{HAL Id: hal-01533314 https://hal.sorbonne-universite.fr/hal-01533314}

Submitted on 6 Jun 2017

HAL is a multi-disciplinary open access archive for the deposit and dissemination of scientific research documents, whether they are published or not. The documents may come from teaching and research institutions in France or abroad, or from public or private research centers.
L'archive ouverte pluridisciplinaire HAL, est destinée au dépôt et à la diffusion de documents scientifiques de niveau recherche, publiés ou non, émanant des établissements d'enseignement et de recherche français ou étrangers, des laboratoires publics ou privés. 


\section{Regulation of Growth: Epigenetic Mechanism?}

\section{Régulation de la Croissance : des Mécanismes Epigénétique?}

Laurent Kappeler $^{1 *}$, Maud Clemessy ${ }^{1}$, Sarah Saget ${ }^{1}$, Lyvianne Decourtye ${ }^{1}$, Yves Le Bouc ${ }^{1}$

1- Sorbonne Universités, UPMC Univ Paris 06, INSERM, UMRS 938, Centre de Recherche St-Antoine (CRSA), 184 rue du Fbg St-Antoine, 75012 Paris, France;

* Corresponding author contact: Laurent Kappeler, Centre de Recherche St-Antoine (INSERM-UPMC UMRS 938), Hôpital St-Antoine, 184 rue du Faubourg St-Antoine, 75012 Paris, France.

E-mail : laurent.kappeler@inserm.fr

Disclosure: A part of the work reviewed here was supported by a grant from Sandoz France laboratories to LK and YLB. 


\begin{abstract}
Organism development is controlled by both genetic programs and the environment to insure a reproductive success as adults. Linear growth is an important part of the development and is mostly controlled by genetic factors. However, the variability of height in a given species does not seem to be specifically associated with SNP. This suggests that environment may play a crucial role. In agreement, an important part of height-related genes present $\mathrm{CpG}$ island in their proximal promoter, indicating potential involvement of epigenetic mechanisms. In mammals, the linear growth is regulated by the IGF system, with IGF-I and IGF-II during the fetal period, and IGF-I being included within the somatotropic axis during the postnatal period. Nutrition during the lactating period programs linear growth and adult size through a modulation of the somatotropic axis development and of the setting of its activity in adulthood. The study of underlying mechanisms suggest two waves of programming, which involve both structural adaptation during the early postnatal period and permanent functional adaptation in adulthood. The former may involve a direct stimulation of axon growth of GHRH neurons by IGF-I in first weeks of life while the latter could involve permanent epigenetic modifications in adulthood.
\end{abstract}

key words : Nutrition, IGF-I, GH, Epigenetic, Ghrh, Axon Growth 


\section{Résumé}

Le développement de l'organisme est contrôlé à la fois par des programmes génétiques et par l'environnement afin d'assurer un succès reproductif à l'âge adulte. La croissance staturale est une partie importante du développement et est principalement contrôlée par des facteurs génétiques. Cependant, la variabilité de la taille chez une espèce donnée ne semble pas entièrement être sous la dépendance du background génétique. Ceci suggère que l'environnement pourrait jouer un rôle crucial. En accord avec cela, une proportion importante des gènes liés à la croissance présentent un îlot $\mathrm{CpG}$ dans leur promoteur proximal, ce qui indique l'implication potentielle de mécanismes épigénétiques. Chez les mammifères, la croissance staturale est régulée par le système IGF, avec l'IGF-I et IGF-II durant la période fotale, et l'IGF-I étant inclus dans l'axe somatotrope lors la période postnatale. La nutrition pendant la période transitoire qu'est l'allaitement programme la croissance staturale et la taille adulte par une modulation du développement de l'axe somatotrope et de son activité à l'âge adulte. L'étude des mécanismes sous-jacents suggère deux vagues de programmation, qui impliquent à la fois une adaptation structurelle en période postnatale précoce et une adaptation fonctionnelle permanente chez l'adulte. La première semble impliquer une stimulation directe de la croissance axonale des neurones GHRH par l'IGF-I dans les premières semaines de vie, alors que la seconde pourrait impliquer des modifications épigénétiques permanentes à l'âge adulte.

Mots clefs : Nutrition, IGF-I, GH, Epigénétique, GHRH, Croissance Axonale 


\section{Text body}

The development of the organism is one of the most complex processes that occur in mammals. It is tightly controlled by both genetic programs and the environment to insure to the organism a proper organogenesis, reach its final height as well as functional regulations that allows a reproductive success as adults. Ninety percent of variation in adult height may be linked to genetic factors. However, studies showed that only a fraction of variability in normal height can be associated with polymorphism by SNP-GWAS (single nucleotide polymorphism-genome wide association studies) [1-3]. This suggests that variability in height is only in part regulated by genetic changes. In the other hand, it has been observed that more than $80 \%$ of genes associated with height contain a $\mathrm{CpG}$ island, site of DNA-methylation in the genome, and that $50 \%$ of them present a transcription associated with their degree of DNA methylation. Thus, epigenetic mechanisms may play a noteworthy role in determination of adult height. In agreement, there is increasing evidence suggesting that perinatal environmental factors play an important role in modifying life -and growth- trajectory.

Growth of fetuses has been associated with both genetic modifications and in response to changes of their environment. The latter was notably observed after exposition of fetuses, through their pregnant mother, to stress, chemicals and denutrition $[4,5]$. In many cases, these expositions induce an intra-uterine growth retardation (IUGR) of fetuses that was furthermore associated with an increased risk to develop cardio-metabolic pathologies in adulthood [5]. Mechanisms involved are believed to involve both structural (anatomic) alterations as well as functional adaptations to the predicted environment that will be experienced later-on. This principle is also known as the Predictive Adaptive Response mecanism and is thought underlie the developmental origin of health and diseases (DOHaD) hypothesis. 
Regarding structural changes, it has been reported that alteration of global environment (nutrition, hormones ...) can induce permanent modification in developing organs and impact cell number for example: in rat model with IUGR induced by a bilateral uterine artery ligation of gestation, it has been reported that the relative $\beta$-cell mass was $50 \%$ of controls in 15-week-old rats, and less than one-third of controls by 26 weeks of age [6, 7].

In addition to structural adaptations, environmental changes can induce functional modifications. These functional modifications can of course be consequences of structural changes, but also directly induced by modifications of the environment. These functional modifications are frequently permanent and a great part of them are believed to involve epigenetic regulations. Epigenetic processes can involve methylation of DNA, posttranslational modifications (PTM) of histones proteins and microRNA. MicroRNAs inhibit RNA translation, acting at the post-transcriptional level. Epigenetic modifications like DNA methylation and histone modifications modulate gene transcription by organizing chromatin conformation and accessibility. DNA methylation mostly occurs at a cytosine positioned immediately before a guanine ( $\mathrm{CpG}$ sites) and these sites are mostly distributed in island. DNA methylation is classically associated with inhibition of gene expression. $\mathrm{CpG}$ island are present in imprinted genes and a subpart of non-imprinted genes. Methylation of DNA in imprinted genes allows the tracking of their parental origin and their repression accordingly. DNA methylation in non-imprinted genes inhibits their transcriptional activity in response to developmental program as well as external (environmental) stimuli. On the other hand, the regulation of gene expression through histones post-translational modifications is more complex. Indeed, histones PTM can stimulate the transcription, promote the elongation of mRNA, or in contrast inhibit the transcription, depending of the histone mark. For example, the acetylation of the lysine 9 of the histone $\mathrm{H} 3$ (H3K9ac) present a permissive effect by relaxing the chromatin conformation while the trimethylation of the lysine 9 of the histone $\mathrm{H} 3$ 
(H3K9me3) inhibit the transcription. However, the trimethylation of the lysine 4 of the histone $\mathrm{H} 3$ (H3K4me3) stimulate the transcription.

First implications of epigenetic mechanisms in the regulation of development following an alteration of nutritional environment were notably highlighted in child of pregnant women that experienced famine in Dutch during the winter at the end of the World War II (the Dutch hunger cohort), which were born small for gestational age. Later on, they also present a higher susceptibility to develop cardio-metabolic pathologies: obesity, insulin resistance, hypertension, etc [8-10]. Depending the period of exposure, imprinted genes and non-imprinted genes can present altered epigenetic marks. Regarding non-imprinted genes, epigenetic alterations have notably been associated with genes involved in the metabolism (e.g. PPAR, RXRA) [11, 12].

Metabolism and linear growth are strongly interrelated and both seem strongly impacted during the perinatal development. Epigenetic modifications seem to be involved in the regulation of linear growth and development as 72 of 87 height-associated genes in Humans contain a $\mathrm{CpG}$ island within their proximal promoter (See for review [13]). Interestingly, the frequency for these genes to host a $\mathrm{CpG}$ island is higher than expected (88\% vs $45 \%$ ). Of note, 25 were found to be imprinted [13]. This is coherent with the observations that alteration of body size is observed in syndromes like Beckwith-Wiedmann, Silver-Russell or Prader-Willi. Concerning non-imprinted height-associated genes, very interesting metaanalyses suggest that some operate as a part of web network. These genes are involved in cell proliferation/apoptosis or have been implicated in cancers when altered [13]. These genes may be modified in response to environmental changes and modulate fetal development accordingly. 
In mammals, fetal and postnatal growths are well-known to also be controlled through circulating factors and hormones like the insulin like growth factors (IGF) and the growth hormone (GH). Two forms of IGF exist, and both IGF-II and IGF-I control the development of the fetus. During the postnatal period, growth become mostly controlled by GH that act notably through IGF-I. Indeed, IGF-I, which is ubiquitously expressed by virtually all cells, is predominantly secreted by the liver in response to GH during the postnatal period.

IGF-I is highly sensitive to the nutritional status during both fetal and postnatal periods. In order to study if regulation of linear growth by nutrition may involve IGF-I, we have used a mouse model. We have modified the nutrition of pups during their lactating period ( $1^{\text {st }}$ to $16^{\text {th }}$ days of life) by changing the litter size at birth by cross fostering [14]. The increase of litter size from 6 to 10 pups per dam induces a restriction in pups while the decrease down to 3 pups per dam induces an overfeeding. In agreement, insulin, leptin and IGF-I circulating levels in 10 days-old lactating pups are changed accordingly. The transient and subtle modification of nutrition during the early postnatal period modulates linear growth and programs final height (naso-anal length) of mice [14]. Interestingly, this variation of linear growth by their transient nutritional modulation is associated with a coherent development of the somatotropic axis. Indeed, mice that experienced a nutritional restriction only during the lactating period are lighter as adults and present with a permanent postnatal growth delay. This is associated in mice from 20 days of age and latter in adults with coherent decrease of GH pituitary contents, circulating IGF-I and ALS plasma levels, growth hormone releasing hormone $(\mathrm{GHRH})$ gene expression in hypothalamus, plus a somatotrophs $\left(\mathrm{GH}^{+}\right.$ cells) pituitary hypoplasia and an increase of somatostatin (SRIH) gene expression in hypothalamus. In contrast, mice overfed during lactation are heavier, taller, and present 
increased GH pituitary content, etc. These results suggest that nutrition during lactation programs linear growth through a modification in the setting of the somatotropic axis.

In addition, we observed that the setting of the developing somatotropic axis by nutrition may involve IGF-I directly. Indeed, the down-regulation of the IGF-I signaling in mouse brain through a heterozygous invalidation of the $I g f-1 R$ in the central nervous system by Cre-Lox approach is also associated with a permanent growth delay [15]. The growth delay observed is counter-intuitive in regard of the well-known negative feedback of IGF-I on the somatotropic axis regulation at the hypothalamic level in adults. These data suggest that IGF-I, during the early post-natal period, stimulates the somatotropic axis before to switch as a negative feedback effectors in adults once the somatotropic axis is fully mature. In agreement, we observed that the growth delay in these transgenic mice present a similar kinetic and alterations as compared with wild-type mice restricted during their lactation: decrease of GH pituitary contents, circulating IGF-I and ALS plasma levels, growth hormone releasing hormone $(\mathrm{GHRH})$ gene expression in hypothalamus, plus a somatotrophs $\left(\mathrm{GH}^{+}\right.$ cells) pituitary hypoplasia and an increase of somatostatin (SRIH) gene expression in hypothalamus. Moreover, results obtained with these mice indicate that the programming of linear growth by nutrition during the early postnatal period involves two waves. The former one is associated with a transient alteration during the first two weeks of life that induces a first adaptation during the early postnatal period. The second wave involves a permanent functional alteration during the adulthood. Since mutant mice present an alteration of IGF-I signaling only in the central nervous system, these data suggest a strong involvement of the hypothalamic part in the setting of the somatotropic axis.

Regarding the first wave, 10 days-old pups carrying the $I g f-1 R$ heterozygous invalidation or restricted in lactation both present a delay of innervation of the median eminence by axons of GHRH neurons. This seems specific since no alteration of median 
eminence innervation by axons of SRIH neurons was noticed in same individuals. GHRH is known to stimulate $\mathrm{GH}$ secretion in adults, but also stimulates the proliferation and the differentiation of somatotrophs during the perinatal period [16]. In this way, a lack of GHRH during this critical window is associated with somatotrophs hypoplasia and postnatal growth retardation. In agreement with the delayed innervation of median eminence by GHRH axon, the start of somatotrophs hypoplasia and lack of GH accumulation in pituitary is observed in mutant mice by 20 days of age. These data suggest that IGF-I may be a potential mainstay in the somatotropic axis and linear growth programming by nutrition during lactation.

The study of underlying mechanisms suggests that IGF-I may directly impact the GHRH neurons development. Since IGF-I is known to modulate multiple cellular process like cell-morphology, proliferation and survival, we first determined if nutritional restriction was associated with any alteration of GHRH neurons ontogeny. Restricted and normally-fed pups present with a similar number of GHRH neurons. Thus, the decreased of median eminence innervation by their axon at 10 days of age suggest a role of IGF-I in cellular development and potentially an alteration of axonal growth. Since GHRH neurons innervate the median eminence through a posteroventral loop highly difficult to follow by classical immunohistochemistry, we applied an in vitro approach by cultivating explants of arcuate nucleus. In agreement with our hypothesis, we observed that IGF-I significantly stimulates the axon growth of GHRH neurons in 24 hours in arcuate explants harvested from normally fed pups [17]. Interestingly, this effect seems preferential since no stimulations were observed for other populations of the arcuate nucleus studied all-at once (i.e. neurofilament ${ }^{+}$axons) or specifically (e.g. $\mathrm{AgRP}^{+}$axons). The axon growth stimulating effect of IGF-I on GHRH neurons involves both the PI3K/AKT and, in a lower extent, the MERK/ERK signaling pathways as revealed by co-stimulations of IGF-I with LY294002 and PD0325901 specific inhibitors, respectively. However, when explants of arcuate nucleus were harvested from 
restricted pups, we observed that GHRH neurons lost their capacities to answer to IGF-I stimulation despite a controlled in vitro environment [17]. Western blot experiments on arcuate nucleus explants suggest that the absence of axon elongation observed for GHRH neurons in restricted pups is associated with impaired activation of the PI3K/AKT signaling pathway, whereas the activation capacity of the ERK/MEK pathway is maintained.

Regarding the second wave of programming of the somatotropic axis by the nutrition during lactation, it seems to particularly involve the SRIH (LK, personal communication). Indeed, both mouse models carrying a heterozygous mutation of $I g f-1 R$ in their central nervous system or those nutritionally restricted during lactation present with increased SRIH gene expression levels in adulthood. SRIH increases after puberty but is not associated any alteration in SRIH neurons number in the periventricular $(\mathrm{PeV})$ nucleus. These changes seem to involve gene regulation and suggest involvement of epigenetic mechanisms. In agreement with this hypothesis Srih promoter contains a CpG island close to its start site. The increase of SRIH gene expression is associated with a coherent lowering of GH gene expression in pituitary.

Thus, current knowledge obtained from transgenic mouse models and wild type one that experienced transient changes of nutritional environment during the lactating period suggest that linear growth can directly be programmed by nutrition. This programming involves adaptation in the set up of the somatotropic axis that regulates postnatal growth in mammals. This programming seems to involve two waves. The first one, during the first two weeks of life, implies a transient structural modification with the axonal growth delay of GHRH neurons, and a permanent one with the pituitary hypoplasia in somatotrophs by 20 days of age onward. The second wave of programming appears thereafter and involves permanent gene expression alteration with the increase of SRIH mRNA. This second wave may involve epigenetic mechanisms like histone PTM and DNA methylation. 


\section{References}

1. Gudbjartsson, D.F., G.B. Walters, G. Thorleifsson, H. Stefansson, B.V. Halldorsson, P. Zusmanovich, P. Sulem, S. Thorlacius, A. Gylfason, S. Steinberg, A. Helgadottir, A. Ingason, V. Steinthorsdottir, E.J. Olafsdottir, G.H. Olafsdottir, T. Jonsson, K. Borch-Johnsen, T. Hansen, G. Andersen, T. Jorgensen, O. Pedersen, K.K. Aben, J.A. Witjes, D.W. Swinkels, M. den Heijer, B. Franke, A.L. Verbeek, D.M. Becker, L.R. Yanek, L.C. Becker, L. Tryggvadottir, T. Rafnar, J. Gulcher, L.A. Kiemeney, A. Kong, U. Thorsteinsdottir, and K. Stefansson, Many sequence variants affecting diversity of adult human height. Nat Genet, 2008. 40(5): p. 609-15.

2. Lettre, G., A.U. Jackson, C. Gieger, F.R. Schumacher, S.I. Berndt, S. Sanna, S. Eyheramendy, B.F. Voight, J.L. Butler, C. Guiducci, T. Illig, R. Hackett, I.M. Heid, K.B. Jacobs, V. Lyssenko, M. Uda, M. Boehnke, S.J. Chanock, L.C. Groop, F.B. Hu, B. Isomaa, P. Kraft, L. Peltonen, V. Salomaa, D. Schlessinger, D.J. Hunter, R.B. Hayes, G.R. Abecasis, H.E. Wichmann, K.L. Mohlke, and J.N. Hirschhorn, Identification of ten loci associated with height highlights new biological pathways in human growth. Nat Genet, 2008. 40(5): p. 584-91.

3. Weedon, M.N., H. Lango, C.M. Lindgren, C. Wallace, D.M. Evans, M. Mangino, R.M. Freathy, J.R. Perry, S. Stevens, A.S. Hall, N.J. Samani, B. Shields, I. Prokopenko, M. Farrall, A. Dominiczak, T. Johnson, S. Bergmann, J.S. Beckmann, P. Vollenweider, D.M. Waterworth, V. Mooser, C.N. Palmer, A.D. Morris, W.H. Ouwehand, J.H. Zhao, S. Li, R.J. Loos, I. Barroso, P. Deloukas, M.S. Sandhu, E. Wheeler, N. Soranzo, M. Inouye, N.J. Wareham, M. Caulfield, P.B. Munroe, A.T. Hattersley, M.I. McCarthy, and T.M. Frayling, Genome-wide association analysis identifies 20 loci that influence adult height. Nat Genet, 2008. 40(5): p. 575-83.

4. Gluckman, P.D., M.A. Hanson, and A.S. Beedle, Early life events and their consequences for later disease: a life history and evolutionary perspective. Am J Hum Biol, 2007. 19(1): p. 1-19.

5. McMillen, I.C. and J.S. Robinson, Developmental origins of the metabolic syndrome: prediction, plasticity, and programming. Physiol Rev, 2005. 85(2): p. 571-633.

6. Simmons, R.A., L.J. Templeton, and S.J. Gertz, Intrauterine growth retardation leads to the development of type 2 diabetes in the rat. Diabetes, 2001. 50(10): p. 2279-86.

7. Thorn, S.R., P.J. Rozance, L.D. Brown, and W.W. Hay, Jr., The intrauterine growth restriction phenotype: fetal adaptations and potential implications for later life insulin resistance and diabetes. Semin Reprod Med, 2011. 29(3): p. 225-36.

8. de Rooij, S.R., R.C. Painter, D.I. Phillips, C. Osmond, R.P. Michels, I.F. Godsland, P.M. Bossuyt, O.P. Bleker, and T.J. Roseboom, Impaired insulin secretion after prenatal exposure to the Dutch famine. Diabetes Care, 2006. 29(8): p. 1897-901.

9. Lumey, L.H., A.D. Stein, H.S. Kahn, and J.A. Romijn, Lipid profiles in middle-aged men and women after famine exposure during gestation: the Dutch Hunger Winter Families Study. Am J Clin Nutr, 2009. 89(6): p. 1737-43.

10. Schulz, L.C., The Dutch Hunger Winter and the developmental origins of health and disease. Proc Natl Acad Sci U S A, 2010. 107(39): p. 16757-8. 
11. Godfrey, K.M., P.M. Costello, and K.A. Lillycrop, The developmental environment, epigenetic biomarkers and long-term health. J Dev Orig Health Dis, 2015. 6(5): p. 399-406.

12. Holland, M.L., R. Lowe, P.W. Caton, C. Gemma, G. Carbajosa, A.F. Danson, A.A. Carpenter, E. Loche, S.E. Ozanne, and V.K. Rakyan, Early-life nutrition modulates the epigenetic state of specific rDNA genetic variants in mice. Science, 2016. 353(6298): p. 495-8.

13. Simeone, P. and S. Alberti, Epigenetic heredity of human height. Physiol Rep, 2014. 2(6).

14. Kappeler, L., C. De Magalhaes Filho, P. Leneuve, J. Xu, N. Brunel, C. Chatziantoniou, Y. Le Bouc, and M. Holzenberger, Early postnatal nutrition determines somatotropic function in mice. Endocrinology, 2009. 150(1): p. 314-23.

15. Kappeler, L., C. De Magalhaes Filho, J. Dupont, P. Leneuve, P. Cervera, L. Perin, C. Loudes, A. Blaise, R. Klein, J. Epelbaum, Y. Le Bouc, and M. Holzenberger, Brain $I G F-1$ receptors control mammalian growth and lifespan through a neuroendocrine mechanism. PLoS Biol, 2008. 6(10): p. e254.

16. Solloso, A., L. Barreiro, R. Seoane, E. Nogueira, C. Canibano, C.V. Alvarez, J. Zalvide, C. Dieguez, and C.M. Pombo, GHRH proliferative action on somatotrophs is cell-type specific and dependent on Pit-1/GHF-1 expression. J Cell Physiol, 2008. 215(1): p. 140-50.

17. Decourtye, L., E. Mire, M. Clemessy, V. Heurtier, T. Ledent, I.C. Robinson, P. Mollard, J. Epelbaum, M.J. Meaney, S. Garel, Y. Le Bouc, and L. Kappeler, IGF-1 Induces GHRH Neuronal Axon Elongation during Early Postnatal Life in Mice. PLoS One, 2017. 12(1): p. e0170083. 


\section{Figures}

Figure 1: Impact of nutrition during the early postnatal period on developing somatotropic axis in mice. Nutrition during the early postnatal period stimulates IGF-I production by all cells of the organism. During the first weeks of life, a first wave of programming of the somatotropic axis occurs. IGF-I stimulates axon growth of GHRH neurons that are located in the arcuate nucleus (Arc) of the hypothalamus. The faster innervation of the median eminence by GHRH axons leads to a clonal expansion of somatotrophs progenitors as well as their differentiation, programming thus the GH production capacity of the pituitary in adulthood. Latter, a second wave induces a permanent alteration of the regulation of SRIH gene expression whose neurons are located in the periventricular nucleus $(\mathrm{PeV})$ of the hypothalamus.

Figure 2: Nutritional Restriction during lactation delay innervation of median eminence by axon of GHRH neurons. The immunohistochemistry against GHRH on coronal section of brain harvested from 10 days-old normally fed (left) and restricted (right) pups indicate a decreased innervation of median eminence by nutritional restriction (arrow). 
Hypothalamus

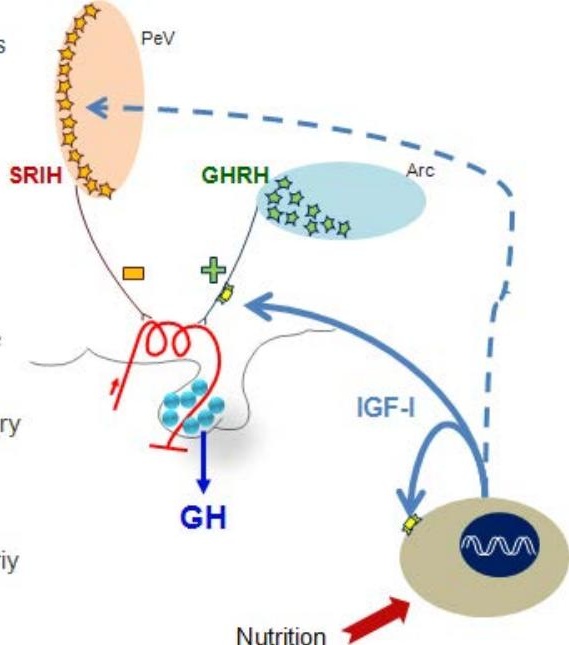


Normally fed Restricted

\section{$\frac{U}{\frac{I}{I}}$}

